\title{
Development of Teaching Modules for Operation and System Stability Courses as a Pilot Project for the Electrical Engineering Study Program Towards Independent Learning
}

\author{
Sujito, Aripriharta, M. Rodhi Faiz, Moh. Zainul Falah, Abdullah Iskandar Syah
}

\begin{abstract}
The challenges of the future of education are increasingly complex. The position of educators in the era of the industrial revolution 4.0 tends to be a facilitator who provides the latest information regarding the development of science. Merdeka Learning is an independent and versatile higher education learning model designed to create an unrestricted creative learning community. This development research resulted in teaching material in the form of learning modules and videos for the Operations and System Stability course. The process of developing modules/teaching materials uses the ADDIE development model, namely Analysis, Design, Development, Implementation, and Evaluating. The teaching materials developed are suitable for students to use based on the results of the formative test data and the Likert scale with $86 \%-100 \%$ being very good criteria. In the one-on-one trial, the percentage of expert eligibility was $94.5 \%$ for digital modules, and 92\% for learning videos. In a small group trial taken from 7 TE 2017 and TE 2018 students, the percentage of eligibility results was $94 \%$ for digital modules, and $94.5 \%$ for learning videos. Meanwhile, in the field trials taken from 76 students of TE 2017 and TE 2018 the results of the feasibility percentage were $91 \%$ for digital modules and $90 \%$ for learning videos.
\end{abstract}

Keywords: Industrial Revolution 4.0, Free Learning, Teaching Materials, Modules, ADDIE Development Model, Operations and System Stability, Merdeka Learning.

\section{INTRODUCTION}

$\mathrm{T}_{\mathrm{t}}$ technology in various sectors will be directly proportional to the development of innovation in teaching and learning activities in universities [1]. Meanwhile, educators as the main actors in learning activities are required to be versatile and master technology in this millennial era [2]. Educators as people who know are also mandated to be able to become facilitators, collaborators, motivators, and evaluators [3]. To answer this, the use of information technology becomes a necessity to be used as a compliment and learning resource to be able to improve understanding of the material which ultimately prepares students to face the challenges of the industrial revolution era 4.0 [4]. To be able to create a comprehensive understanding of the material, it is necessary to collaborate or innovate in the process of teaching and learning activities that facilitate learning objects and subjects to understand easily accessible teaching materials and teaching content.

The challenges of the future of education are increasingly complex. The future education system faces different challenges that require different approaches in the delivery of higher education. The challenge is no longer a competition for

- Sujito, Ph.D. Department of Electrical Engineering. State University of Malang. Malang. E-mail: sujito.ft@um.ac.id

- Aripriharta, Ph.D. Department of Electrical Engineering. State University of Malang. Malang. E-mail: aripriharta.ft@um.ac.id

- M. Rodhi Faiz, M.T. Department of Electrical Engineering. State University of Malang. Malang. E-mail: mohammad.rodhi.ft@um.ac.id

- Moh. Zainul Falah, S.T. State University of Malang. Malang. E-mail: mzainulfalah@gmail.com

- Abdullah Iskandar Syah, S.T. State University of Malang. Malang. E-mail: abd.iskandar27@gmail.com knowledge but a competition for creativity, a competition for imagination, a competition for learning, competition for free thinking. The situation in the future is also faced with various conditions of Volatility, Uncertainty, Complexity, and Ambiguity (VUCA). In the end, students must be able to adapt to every change, every condition, and remain independent people. The Ministry of Education and Culture responded to this by issuing several new policies on January 24, 2020, including the Merdeka Learning - Merdeka Campus policy. Merdeka Learn-Independence Campus is an independent and versatile higher education learning model designed to create an unrestricted creative learning community that meets the needs of students in the face of changing environmental conditions, full of uncertainty and complexity of problems [5].

Operations and system stability courses are courses taken by undergraduate students. The course consists of theoretical discussions and simulations. For theoretical discussion, students can learn through learning resources from reference books from course lecturers and also the use of simulation software available in the department's laboratory. Meanwhile, the current situation regarding the COVID-19 pandemic has caused distance learning to be carried out so that there is a need for learning innovations through media to support student needs, namely the need for teaching materials that can be accessed at any time such as learning videos and teaching modules.

The position of educators in the era of the industrial revolution 4.0 tends to be facilitators who provide the latest information regarding the development of science to students from various circles. resources, so educators must have 
competence in technology and digital (Setiawan et al. 2019). With the help of the media can simplify the complexity of the material presented to students [6]. Currently, technology-based learning media have been widely developed. This type of learning media can not only add value to the function and use of technology [7], it can also improve student academic achievement [8]. Academic achievement can include cognitive learning outcomes, learning motivation, and learning independence. One of the programs that can be developed into interesting learning media is learning videos, teaching materials/books with ISBN.

\section{RESEARCH METHODS}

This research is included in the type of research and development, commonly called research and development (R\&D). Sugiyono believes that research methods are used to produce products and test the effectiveness of these products [10]. [11] put forward another view that research and development aim to produce new products through the development process. In general, $R \& D$ is research that aims to produce new products and test the effectiveness of these products. This study uses the ADDIE development model, which is a development model consisting of five stages, namely Analysis, Design, Development, Implementation, and Evaluating, but this study is limited to the implementation stage. Because in this development study, only the feasibility of the product being developed is evaluated, the effectiveness of the learning media products/teaching materials is not evaluated.

Several sources of data in this study used questionnaires from media experts, material experts, and resource persons. According to [10] data collection is answered by providing a series of written questions to respondents. Questionnaires were used to measure the quality of the developed media. The questionnaire in this study was used to obtain data from media experts, material experts, and resource persons as an evaluation material for the developed learning media. Writing this questionnaire using a Likert scale. The use of qualitative and quantitative data in this study was used to develop data collection procedures in learning media. Qualitative data in the form of suggestions and input from media experts and material experts. Quantitative data in the form of assessment data about learning media based on audio studio media player from material experts, media, and respondents.

The data sources in this study were 2 experts, namely 1 material expert and 1 media expert as a one-on-one trial. Then continued trials in small groups which were used as many as 7 students for students and 76 students for large group field tests. The instrument used is a media assessment questionnaire for media experts, material experts, and students. The data collection technique used is the observation of undergraduate students in Electrical Engineering and provides expert validity questionnaires and student feedback. The quality of the learning media data based on audio media studio is in the form of percentage descriptive data.

The media validation and the resulting discussion were carried out by media expert validators and material experts and then analyzed using a descriptive percentage technique with the formula [9]:

$V=\frac{T S e}{T S h} x 100 \%$

V: Validation (expect1, expect2, student)

TSe: Total empirical score achieved

TSh: Total maximum score

To decide to determine whether or not the teaching materials developed are appropriate, the assessment qualification criteria are used. According to [9] the developer can determine the validity criteria personally which is adjusted to the number of items in the instrument. From this statement, validity and feasibility criteria can be determined using the following equations:

Value interval $(\mathrm{IN})=\frac{\text { score different }}{\sum \text { Class interval }}$

Score difference $(\mathrm{SS})=$ Maximum - Minimum score

Maximum score $=$ item $\times$ Highest score

Minimum score $=$ item $\times$ Lowest score

Validity percentage interval (IV) $=\frac{\text { value interval }}{\text { maximum score }} \times 100 \%$

Questionnaire data processing uses a Likert scale, the following scores are used (Purwanto, 2013):

Table 1 Likert Scale

\begin{tabular}{|l|l|}
\hline Percentage & Criteria \\
\hline $86 \%-100 \%$ & Very Good \\
\hline $76 \%-85 \%$ & Well \\
\hline $60 \%-75 \%$ & Enough \\
\hline $55 \%-59 \%$ & Not Good \\
\hline
\end{tabular}

\section{Analysis Results}

The product design results in this research and development are in the form of teaching materials that contain modules and learning videos on Operations and System Stability for the Operations and System Stability course. The design of the development of this teaching material uses the ADDIE development model. The development process is divided into five steps, namely (1) analyze, (2) design, (3) develop, (4) implement, and (5) evaluate.

The design of the Operations and System Stability module according to the Daryanto format (2014: 193) which has been adapted according to needs consists of (1) cover, (2) introduction, (3) introduction, (4) learning materials, (5) summary, (6) formative test, (7) list of references. While the structure of the video refers to [12] which has been adapted as needed as it consists of: (1) front page, (2) learning objectives, (3) apperception, (4) learning materials. Trial data in the form of data from one-on-one trials, small group trials, and field trials. The data from the one-on-one trials were obtained from 
the validation results of expert 1 and expert 2 . While the data from the small group trial results were obtained from distributing questionnaires to 52018 TE students and 22017 TE students. Field trials were obtained by distributing questionnaires to 76 TE students. 2017 and TE 2018 who are currently taking and have taken the Operations and System Stability course:

\section{A. Flowchart Presentation and Data Analysis of One-on-One Trial} Results

The data on the results of the one-on-one trial were obtained from expert 1, namely Imron Ridzki, and expert 2, namely Syarifuddin. Presentation of the data from the one-on-one trial. The explanation of the results of the one-on-one test assessment by expert 1 and expert 2 for digital modules and learning videos is as follows: :

a. Module

Details of quantitative data from the results of the one-onone trial assessment for the module by expert 1 and expert 2 are shown in Table 2.

Table 2 Presentation of Expert Test Result Data Module

\begin{tabular}{lllll}
\hline No & $\sum$ Tse & $\sum$ Tsh & $\begin{array}{l}\text { V-ah } \\
(\%)\end{array}$ \\
\hline Expert 1 & & & \\
\hline $1 \quad$ & Content Eligibility & 40 & 40 & 100 \\
2 & Language Eligibility & 23 & 24 & 96 \\
3 & Serving Eligibility & 32 & 32 & 100 \\
4 & Graphic Eligibility & 12 & 12 & 100 \\
\hline \multicolumn{2}{l}{ Total } & $\mathbf{9 5}$ & $\mathbf{1 0 8}$ & $\mathbf{9 9}$ \\
\hline Expert 2 & & & \\
\hline 1 & Content Eligibility & 35 & 40 & 88 \\
2 & Language Eligibility & 21 & 24 & 88 \\
3 & Serving Eligibility & 27 & 32 & 84 \\
4 & Graphic Eligibility & 12 & 12 & 100 \\
\hline Total & $\mathbf{1 0 1}$ & $\mathbf{1 0 8}$ & $\mathbf{9 0 . 0 0}$ \\
\hline Average & & & $\mathbf{9 4 . 5 0}$ \\
\hline
\end{tabular}

Description:

$\begin{array}{ll}\text { V-ah }(\%) & =\text { Expert validation. } \\ \text { Tse } & =\text { Total empirical score achieved. } \\ \text { Tsh } & =\text { Total maximum expected score. }\end{array}$

Based on the module validation analysis by expert 1 and expert 2, the average per aspect is $94.50 \%$, which is included in the very valid criteria. This is following the criteria that there is a percentage of $86 \%-100 \%$ included in the very good criteria.

\section{b. Tutorial Video}

Details of quantitative data from the results of the one-onone trial assessment for videos by expert 1 and expert 2 are shown in Table 3.
Table 3 Presentation of One-on-One Test Result Data for Video

\begin{tabular}{|c|c|c|c|c|c|}
\hline No & Value Aspect & $\sum$ Tse & $\begin{array}{c}\sum_{\mathbf{h}} \mathbf{T s} \\
\end{array}$ & $\begin{array}{l}\text { V-ah } \\
(\%)\end{array}$ & $\begin{array}{c}\text { Keterang } \\
\text { an } \\
\end{array}$ \\
\hline \multicolumn{6}{|c|}{ Expert1 } \\
\hline 1 & Learning Design & 28 & 32 & 88 & $\begin{array}{l}\text { Very } \\
\text { Good }\end{array}$ \\
\hline 2 & Visual Communication & 35 & 40 & 100 & $\begin{array}{l}\text { Very } \\
\text { Good }\end{array}$ \\
\hline Tota & & 85 & 96 & 94 & $\begin{array}{l}\text { Very } \\
\text { Good }\end{array}$ \\
\hline \multicolumn{6}{|c|}{ Expert 2} \\
\hline 1 & Learning Design & 27 & 32 & 84 & $\begin{array}{l}\text { Very } \\
\text { Good }\end{array}$ \\
\hline 2 & Visual Communication & 32 & 32 & 100 & $\begin{array}{l}\text { Very } \\
\text { Good }\end{array}$ \\
\hline Tota & & 94 & 96 & 97.91 & $\begin{array}{l}\text { Very } \\
\text { Good }\end{array}$ \\
\hline Ave & & & & 92 & Very Good \\
\hline
\end{tabular}

Based on the analysis of the video validation results by exefrangat expert 2, the average per aspect is $92 \%$, which is included in the very valid criteria. This is following the existing criteria that the percentage of $86 \%-100 \%$ is included in the very gSangatibarit.

Sangat Baik

BSaPgetelation and Data Analysis of Small Group Trial Results Saipget daith from the small group trial results were obtained frangatsbailents who are currently taking or have taken the Operations and System Stability course with details of 52018 T\$arsqudlenits and 22017 TE students. The following is an asahgsis befimodule data and learning videos.

Sangat baik aSaMgadlud k

SaQganbidquive data were obtained from three aspects, namely asqaftatofialpearance, presentation, and benefits which are translated into 20 items. The presentation of the data from the small group trial results for the module is shown in Table 4.

Table 4 Presentation of Small Group Trial Results Data for Modules

\begin{tabular}{llcclc}
\hline No & Aspect & Tse & Tsh & $\begin{array}{l}\text { V-au } \\
(\mathbf{\%})\end{array}$ & Description \\
\hline 1 & $\begin{array}{l}\text { Display } \\
\text { Aspect }\end{array}$ & 191 & 196 & 97 & Very Good \\
2 & $\begin{array}{l}\text { Presentation } \\
\text { Aspect } \\
\text { Benefit } \\
\text { Aspect }\end{array}$ & 233 & 252 & 92 & Very Good \\
& 104 & 112 & 93 & Very Good \\
\hline Total & $\mathbf{5 2 8}$ & $\mathbf{5 6 0}$ & $\mathbf{2 8 2}$ & Very Good \\
\hline Average & & & $\mathbf{9 4}$ & Very Good \\
\hline
\end{tabular}

Description:

$\mathrm{V}$-au $=$ Audience validation .

Tse $=$ Total empirical score achieved . 
Tsh $=$ Total maximum expected score

Based on the analysis of the results of the small group trial, it was found that the average percentage per aspect was $93.25 \%$ which was included in the very valid criteria. This is following the criteria contained in Table 2 that the percentage of $86 \%$ $100 \%$ is included in the very good criteria.

\section{b. Tutorial Video}

Quantitative data were obtained from three aspects, namely aspects of software engineering, learning design, and visual communication which were translated into 20 items. The presentation of data from small group trials for video is shown in Table 5. and more fully is presented in Appendix 10.

Table 5 Presentation of Small Group Trial Result Data for Video

\begin{tabular}{llcccc}
\hline No & Aspect & Tse & Tsh & $\begin{array}{l}\text { V-au } \\
(\mathbf{\%})\end{array}$ & Descriptiom \\
\hline $1 \quad \begin{array}{l}\text { Aspects of } \\
\text { Learning Design }\end{array}$ & 222 & 224 & 99 & Very Good \\
$\begin{array}{l}\text { Visual } \\
\text { Communication }\end{array}$ & 201 & 224 & 90 & Very Good \\
& & & & \\
\hline Aspect & $\mathbf{4 2 3}$ & $\mathbf{4 4 8}$ & $\mathbf{1 8 9}$ & Very Good \\
\hline Total & & & $\mathbf{9 4 . 5}$ & Very Good \\
\hline Average & & & & \\
\hline
\end{tabular}

Based on the analysis of the results of the small group trial, the average percentage per aspect was 94.5\% which was included in the very valid criteria. This is following the existing criteria that the percentage of $86 \%-100 \%$ is included in the very good criteria.

Presentation and Analysis of Field Trial Results

The data from the field trials were obtained from 76 students who are currently taking or have taken the Operations and System Stability course. The following is an analysis of the module data and learning videos.

c. Module

Quantitative data is taken from three aspects, namely aspects of appearance, presentation, and benefits which are translated into 20 items. The presentation of the data from the field trial results is shown in Table 6.

Table 6 Presentation of Field Trial Result Data for Module

\begin{tabular}{|c|c|c|c|c|c|c|}
\hline No & Aspect & Tse & Tsh & $\begin{array}{l}\text { V-au } \\
(\%)\end{array}$ & Description & $\begin{array}{l}\text { learning video consists of the front page, learning objectives, } \\
\text { Katepangantion, learning materials. } \\
\text { The teaching materials developed are suitable for students }\end{array}$ \\
\hline 1 & $\begin{array}{l}\text { Display } \\
\text { Aspect }\end{array}$ & 1987 & 2128 & 93 & $\mathrm{C}$ & $\begin{array}{l}\text { Sangateditklearning the Operations and System Stability course } \\
\text { based on the results of formative test data. In the one-on-one }\end{array}$ \\
\hline 2 & $\begin{array}{l}\text { Presentation } \\
\text { Aspect }\end{array}$ & 2468 & 2736 & 90 & ood & $\begin{array}{l}\text { Sanigat baekpercentage of expert eligibility was } 94.5 \% \text { for digital } \\
\text { modules, and } 92 \% \text { for learning videos. In the small group trial, }\end{array}$ \\
\hline 3 & $\begin{array}{l}\text { Benefit } \\
\text { Aspect }\end{array}$ & 1092 & 1216 & 90 & tood & $\begin{array}{l}\text { Sahgatedeikntage of eligibility results was } 94 \% \text { for digital modules, } \\
\text { and } 94.5 \% \text { for learning videos. Meanwhile, in the field trial, the }\end{array}$ \\
\hline \multicolumn{2}{|c|}{ Total } & & 6080 & 273. & ery & Vpercenatage of feasibility results was $91 \%$ for digital modul \\
\hline \multicolumn{2}{|c|}{ Average } & & & 91 & Very Good & ddfor learning videos \\
\hline
\end{tabular}

Based on the analysis of the results of field trials, the average percentage per an aspect of the whole is $91 \%$, which is included in the very valid criteria. This is following the criteria contained in Table 2 that the percentage of $86 \%-100 \%$ is included in the very good criteria.

\section{d. Tutorial Video}

Quantitative data is taken from three aspects, namely aspects of software engineering, learning design, and visual communication which are translated into 20 items. The presentation of data from field trials for video is shown in Table 7.

Table 7 Presentation of Field Trial Result Data for Video

\begin{tabular}{llllll}
\hline No & Aspect & Tse & Tsh & $\begin{array}{l}\text { V-au } \\
(\mathbf{\%})\end{array}$ & Description \\
\hline $1 \quad \begin{array}{lllll}\text { Aspects } \\
\text { Learning }\end{array}$ & of & 2216 & 2432 & 88.87 & Very Good \\
$\begin{array}{l}\text { Design } \\
\text { Visual } \\
\text { Communication } \\
\text { Aspect }\end{array}$ & 2155 & 2432 & 88.14 & Very Good \\
& & & & \\
\hline Total & $\mathbf{4 3 7 1}$ & $\mathbf{4 8 6 4}$ & $\mathbf{1 8 0}$ & Very Good \\
\hline Average & & & $\mathbf{9 0}$ & Very Good \\
\hline
\end{tabular}

Based on the analysis of the results of field trials, it was found that the average percentage per aspect was $88.6 \%$ which was included in the very valid criteria. This is following the criteria contained in Table 2 that the percentage of $86 \%-100 \%$ is included in the very good criteria.

\section{Conclusion}

The resulting product is Operations and Stability teaching materials in the form of learning modules and videos. The materials discussed in this digital teaching material are (1) Contingency Analysis in the System, (2) Load Distribution on the System, (3) Unit Commitment and Economic Dispatch, (4) System Dynamic Modeling, (5) System Stability (6 ) System Control.

The module components consist of the cover page, preface, table of contents, list of pictures, concept map, introduction, learning materials, summary, formative test, list of references. The developed digital module is accompanied by formative test answer keys and assessment guidelines which are placed separately from the digital module. While the learning video consists of the front page, learning objectives, The teaching materials developed are suitable for students ogaseaiklearning the Operations and System Stability course modules, and $92 \%$ for learning videos. In the small group trial,

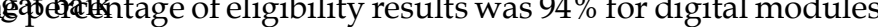
VandQ68dffor learning videos. 
DOI: $\underline{\text { HTTPS://DOI.ORG/10.53893/IJRVOCAS.V114.74 }}$

\section{ACKNOWLEDGMENT}

The development of the Operational and System Stability Teaching Module as a Pilot Project for the Electrical Engineering Undergraduate Study Program Towards Independent Learning was funded by PNBP research funds, State University of Malang

\section{REFERENCES}

[1] Ion, Georgeta, Elena Cano, and Nati Cabrera. 2016. “Competency Assessment Tool (CAT). The Evaluation of an Innovative Competency-Based Assessment Experience in Higher Education." Technology, Pedagogy and Education 25(5):631-48. doi: 10.1080/1475939X.2015.1134635.

[2] Harrati, Nouzha, Imed Bouchrika, and Zohra Mahfouf. 2017. "Investigating the Uptake of Educational Systems by Academics Using the Technology to Performance Chain Model." Library Hi Tech 35(4):629-48. doi: 10.1108/LHT-01-2017-0029

[3] Anderson, D. 2017. "Improving Information Technology Curriculum Learning Outcomes."

[4] Sagita, Mustakim, and Khairunnisa Khairunnisa. 2020. "E-Learning for Educators in Digital Era 4.0." Budapest International Research and Critics Institute (BIRCI-Journal): Humanities and Social Sciences 3(2):1297-1302. doi: 10.33258/birci.v3i2.974

[5] Lhutfi, Iqbal, and Rika Mardiani. 2020. “Merdeka Belajar - Kampus Merdeka Policy: How Does It Affect the Sustainability on Accounting Education in Indonesia?" Dinamika Pendidikan 15(2):243-53. doi: 10.15294/dp.v15i2.26071

[6] Arsyad, A. 2011. Media Pembelajaran. Cetakan Ke-15. Jakarta: Rajawalli Pers.

[7] Calimag, J. N., P. A. Mugel, Romel S. Conde, and Luisa B. Aquino. 2014. "Ubquitous Learning Environment Using Android Mobile Application." International Journal of Research in Engineering $\mathcal{E}$ Technology 2(2):119-28.

[8] Chuang, Tsung-Yen, and Wei-Fan Chen. 2007. "Effect of Digital Games on Children's Cognitive Achievement." J. Multim. doi: 10.4304/jmm.2.5.27-30

[9] Akbar, Sa'dun. 2013. Instrumen Perangkat Pembelajaran. Bandung: PT Remaja Rosdakarya.

[10] Munir, and Munir. 2013. "Multimedia: Konsep \& Aplikasi Dalam Pendidikan / Munir." 1. PENDIDIKAN AUDIO - VISUAL <BR $>2$. PENDIDIKAN - MEDIA,Multimedia: Konsep \& Aplikasi Dalam Pendidikan / Munir 2013(2013):1-99. doi: 2013

[11] Budiman, I., A. Sukandi, and A. Setiawan. 2008. “Model Pembelajaran Multimedia Interaktif Dualisme Gelombang Partikel Untuk Meningkatkan Pemahaman Konsep Dan Ketertampilan Berfikir Kritis." Jurnal Penelitian Pendidikan IPA 2(1):17-21

[12] Prastowo, Andi. 2011. Panduan Kreatif Membuat Bahan Ajar Inovatif. Yogyakarta: DIVA press. 